\title{
Influência do código de pontuação na sistematização do treino da ginástica artística masculina
}

\author{
Influence of code of points in training systematization \\ of mens artistic gymnastics
}

Paulo D.S. Carrara ${ }^{1}$

Resumo - O objetivo deste estudo foi verificar a influência do Código de Pontuação (CP) 2006 na sistematização do treino da Ginástica Artística Masculina de alto nível. A fim de compreender estas alterações, oito treinadores da categoria senior de seleções nacionais - Portugal e Brasil - foram questionados sobre as mudanças nas regras do CP e respectiva influência no treino. Para as entrevistas, foi realizada previamente uma análise comparativa entre as regras dos CPs de 2001 e 2006, a partir da qual foram construídos e validados os questionários. Dois questionários de doze itens cada foram respondidos e comentados, como também quatro questões complementares. Para análise dos itens, foi utilizada estatística descritiva (média e desvio padrão) e inferencial (Mann-Whitney). Para os comentários, foi utilizada a análise de conteúdo. Não foram encontradas diferenças estatisticamente significativas entre as respostas aos itens dos dois questionários referentes aos treinadores dos dois países. Porém, no que concerne aos comentários, os treinadores manifestaram algumas tendências em ocorrer as devidas mudanças no treino. Assim, na Preparação Física, ocorreu aumento do volume e intensidade do treino; na Preparação Técnica, foi necessária a maior variedade e dificuldade de elementos dos diferentes grupos; na Preparação Tática, verificaram-se Exercícios com maior número de elementos de maior dificuldade, inclusive a saída. Os principais resultados permitiram concluir que o CP 2006 determinou mudanças na composição dos Exercícios, onde houve a utilização de um número mais variado de elementos nos Aparelhos. A performance dos ginastas nos diferentes Aparelhos é condicionada não somente pelas características do treino, como também pelo potencial individual dos ginastas. Pode-se inferir que o processo de formação técnica do ginasta deve ser mais diversificado.

Palavras-chave: Ginástica; Educação física e treinamento; Tendências.

Abstract - The aim of this study was to determine the influence of the 2006 Code of Points (CP) on the systematization of high level men's artistic gymnastics training. To understand these alterations, eight senior coaches of national teams - Portugal and Brazil - were questioned about the changes in the CP rules and their respective influence on training. For the interviews, a comparative analysis between the rules of the 2001 and $2006 \mathrm{CP}$ was performed, whose results were used to construct and validate the questionnaires. Two questionnaires of 12 items each, as well as four complementary questions, were answered and commented upon. Descriptive (mean and standard deviation) and inferential (Mann-Whitney test) statistics was used for analysis of the items. Content analysis was used for evaluation of the comments. No significant differences were observed between the answers to the items of the two questionnaires given by the coaches of either country. However, regarding comments, the coaches expressed some tendencies toward training changes. In this respect, an increase in training volume and intensity was introduced into Physical Preparation; in Technical Preparation a wider element variety

1 Universidade do Porto. Faculdade de Desporto. Mestrado em Ciências do Desporto. Porto, Portugal. 2007.

Orientador: Prof. Manuel Botelho. Co-orientador: Prof. Carlos Araújo. and element difficulty of the different groups were necessary; in Tactical Preparation routines involving a larger number of more difficult elements, including dismount, were observed. The main results permit to conclude that the $2006 \mathrm{CP}$ led to changes in routine composition, with the use of a more varied number of elements on the apparatuses. Gymnast performances on the different apparatuses is not only conditioned by training characteristics, but also by the gymnast's individual potential, inferring that the process of technical development of the gymnast should be more diversified.

Key words: Gymnastics; Physical Education and Trainning, Trends. 